\title{
Speaking, feeling, mattering: Theatre as method and model for practice-based, collaborative, research
}

\section{Abstract}

This paper examines uses of theatre for practice-based, collaborative, research. It brings a review of existing work and reflections on my own practice into dialogue with participatory geographies, studies of affect and geographies of bodily difference. This demonstrates in-depth and well-justified relationships between forms of practice and the spatial ways of knowing they engage; the surfacing of otherwise background conditions for critique and intervention; and how particular relations between doing and thinking, as well as between collaborating partners, can open a field of possibilities. This is significant for the broader development and assessment of 'creative' or 'artful' collaborations in human geography, as I summarise in conclusion.

\section{Key Words}

Affect, bodily difference, collaboration, creative practice, participation, theatre,

\section{Acknowledgments}

Thank you to editors and reviewers who have been thoughtful and supportive throughout this process, demonstrating the best of back-stage care (collaboration!) Thanks also to Louise Amoore, Ben Anderson, Roger Burrows, Rebecca Coleman, Rachel Colls, Helen Nicholson, Julia Heslop, Rachel Pain, and Divya Tolia-Kelly for direct or indirect comments and/or discussion about the paper at various stages along the way. Finally, for advice on the play, thanks to Jill Heslop, Catrina McHugh, our women's group and David Raynor.

Introduction: she speaks, she feels, she matters...

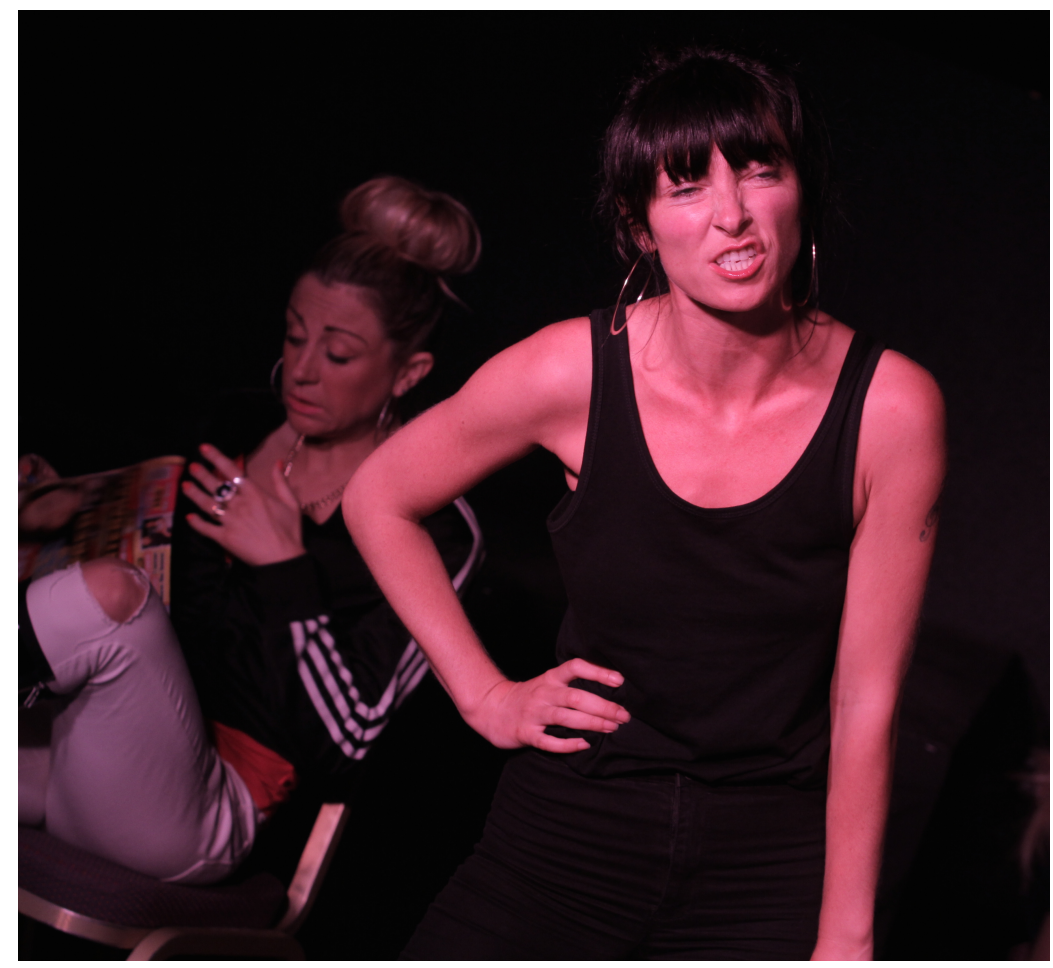

Still from 'DieHard Gateshead' (2015) written by (author) with women from a UK family support group, produced by Theatre of Moths and directed by Neil Armstrong: image features Christina Dawson and Jessica Johnston: Photo credit- Matt Jamie Photography.

As the actor speaks air is expelled from the lungs. The vocal folds vibrate. But even in silence she has a voice through gesture, poise, and attitude, a body; breathing, sexed, fleshy, skin; coloured and textured. She breathes, I breathe. And how I listen lifts or deadens the mood... 
What can be learned from this staged encounter? What changes result from it? How does it matter; the sharing or not, of a breath in a place? Bearing these questions in mind, I explore uses of theatre for collaborative research and consider their implications for other practice-based ${ }^{1}$ methods that are 'artful' or 'creative' in human geography (Crang, 2003; Pain, 2004; Hawkins 2013a, 2015; Shaw et al., 2015). It is old news that rifts between social science and art, theory and practice, research and its' dissemination are regularly bridged in this discipline. Diverse methods like story-telling, (Lorimer, 2003; MacDonald, 2013), drawing (Eggleton et al., 2016; Tolia-Kelly, 2001), therapeutic art making, (Boyd, 2017a) photography and cinematography (Latham, 2008; Garrett, 2015), site-specific performance (Pearson, 2011), and phonographic and polyphonic methods (Gallagher \& Prior, 2014) are increasingly deployed, and regularly listed. However, what really matters are the conceptual foundations of these bridges, their purpose, the bodies that build them, the techniques and materials that they use, what they enable. Current inquiry shows how creative practices (with focus on visual arts) support the 'knowing', and 'representing' of place, and calls for more attention to how they might intervene in the making or re-making of places (Hawkins, 2015; Marston and Deleeuw, 2013). Meanwhile, some creative, participative research in human geography is accused of gimmickry whilst its 'excellence' is brought into question. This work, it is argued, is neither theoretically innovative nor aesthetically compelling. ${ }^{2}$ Here I unpick these terms of assessment giving some focus to what might be meant by 'intervention.' In part, this means refusing to homogenise so-called 'creative methods' ${ }^{3}$ which can differently enact, reveal and respond to practices and technologies of world-making (McCormack, 2017, Thrift 2011). Whilst drawing my own theatre-making methods ${ }^{4}$ into dialogue with participatory geographies, studies of affect and bodily difference, I review and expand on what, specifically, theatre can enable within and between these sub-disciplinary approaches in human geography (and vice-versa). This informs a set of provocations to support the development and assessment of broader creative research practices, whilst holding onto their diversity.

Collaborators can 'speak, feel and matter,' in theatre for research as they make, attune and respond to conditions of their own and each others' becoming. This emphasises relations between felt and embodied, critical and analytic ways of knowing that are enabled by different theatre practices (Allegue et al., 2009; Kershaw and Nicholson, 2011). Further a 'strange'

\footnotetext{
${ }^{1}$ There is a distinction between practice-based and practice-led research. The former uses practice as a basis for the generation of knowledge, the latter is concerned with the nature of practice and has significance for that practice. As in this case, their boundaries can become blurred, and here I use the term 'practice-based' in its broadest possible sense.

${ }^{2}$ This refers to a specific set of concerns raised at the RGS-IBG 2018 panel, 'The Question of Culture in Cultural Geographies.'

${ }^{3}$ Though I recognize the usefulness of this umbrella term and the important critical work that has been deployed under the rubric 'creative geographies,' and 'geo-humanities.'

${ }^{4}$ I refer to 'theatre for research' and 'theatre as method' throughout to denote theatre-making processes and techniques that are deployed for the generation of research in human geography. For context, see the growth in disparate fields of 'performative social science' (Gergen and Gergen, 2011; Leavy, 2015).
} 
space delineated by theatre performances, games, and exercise, can surface otherwise hidden material-affects, making room for critique and in turn, intervention ${ }^{5}$. In this way, questions concerning how a body moves through space, how affects that resonate are evoked in a scene, how the life events of a fictional character are decided, become methodologically significant. This justifies an expansion of what counts as research material to include drawn and written notes, audio and visual recordings of theatre practices and theatre making processes; other co-produced outputs from development - for example, a character's time-line, or a 'roll on the wall' describing her hopes and fears; collaborative and/or autonomous reflections on what these processes reveal and enable; as well as written scripts, scenes, situations, live performances and their various archives. The value of this work is held in in-depth and well-justified relationships between forms of practice and the spatial knowledges they engage and enable; how collaborators interact, think and feel as a result of these processes; and the multiple forms of embedded and embodied, iterative learning that take place on the bridges, and between collaborating partners.

In geography to date, testimonial theatre is used to enliven and disseminate stories from the field (Rogers, 2017). What are in some circumstances unheard or excluded perspectives are gathered through talk-based methods, including interviews and focus groups, before being staged and circulated (Johnston and Pratt, 2010; Richardson, 2015). Theatre practices are also used to engage witnesses, spect-actors, or participants in the experience and co-generation of research-creation (Pratt and Johnston, 2007; Johnston and Pratt, 2010). Stories and scenes are not just gathered, disseminated, and at times disembodied - they are also co-created. By drawing on studies of embodiment and bodily difference I show how this can broaden approaches to boundary crossing that are central to participatory geographies. For example, to date geographers have described their own affective experiences of the performing arts, centring their creative, and lively potentialities whilst making interventions in the discipline (McCormack, 2005, 2008, 2014; Simpson, 2009, Rogers, 2012). This work has often involved some form of participation but focus is not typically given to in-depth collaborative exploration of affective situations. ${ }^{6}$ I show approaches that facilitate collective attunement to affective flows and intensities that become palpable through theatre practice. Collaborators can diagnose, reflect on and improvise experiments with affective conditions together. Relatedly, theatre-making techniques can support and extend a growing field of work on geographies of bodily difference furthering their connections with a politics of affect (on which see Longhurst, 2001; Colls, 2012; Longhurst and Johnston, 2014). 'Matter' in the title of this paper then, refers to the centrality of the body and what materialises through the body in performance. This means that different bodies hold and wear lived experiences in specific ways through theatre

\footnotetext{
${ }^{5}$ Amoore and Hall (2010) have been instrumental here, particularly on the nuanced capacities of site-specific art to reveal and contest otherwise discrete techniques and technologies of border security.

${ }^{6}$ For example, Rogers $(2010,2012)$ as assistant stage manager supported a professional production of American-Asian play Solve for $X$, then developed theoretical interventions based on these experiences.
} 
making practice. The body is central to the participatory process - to the making and dissemination of collaborative research. The mattering of research collaborators is extended from 'having voice' through speech to how different bodies feel and become present otherwise in co-produced research.

This paper performs the kind of practice-based (and practice-led) learning that it seeks to interrogate by showing how scenes, stories and experiences from the field make conditions for theoretical innovation (Rose, 2016; McCormack, 2017). Further it demonstrates how interventions from the discipline become knitted into explorative 'sense-making' processes with collaborating partners. Current uses of theatre and other performing arts for research in geography - as they speak to practice-based methodologies in the fields that I have identified - are brought into dialogue with a specific theatre-making project. This was developed over a two-year period with women attending a family support service in the North East of England. ${ }^{7}$ Collaborators were all out of paid work or in precarious low paid employment, often with unpaid care responsibilities. We developed a fictional play that engaged with and made visible women's lived experiences in austerity. This was staged in local theatres and community centres alongside post-show discussion. Drawing on that process I tease out the significance of theatre methods for practice-based collaboration in three main parts. The first part deals with 'speaking' and an ethics of boundary crossing that is central in participatory geographies. The second part tackles 'feeling,' and extends a participatory ethics of collaboration to emotional and affective geographies of theatre, and the third part on 'mattering' examines uses of the body as a tool and object of analysis in creative-research. Three parts combine to demonstrate discursive, fleshy and visceral forms of co-production/experimentation that are enabled by uses of theatre for research. ${ }^{8}$ By thinking/doing more with these alternative forms of expression we can move beyond emphasis on discourse to explore (and intervene in) multiple forces that make and shape lived experiences - that in turn provide the conditions for possibility. This demonstrates a purposeful and multi-directional relationship whereby creative research practices develop from, move and move with sub-disciplinary concerns. These findings have broader implications for understanding the becoming sense-able and valuable of practice-based collaborations in human geography, which I summarise in conclusion.

\section{Speaking: Weaving, feeling, narratives}

\footnotetext{
${ }^{7}$ The first phase was led by Newcastle based drama-educator, Donna Tonkinson, with a group of 11-20 women (12 core members). Women chose to remain anonymous but selected their own pseudonyms, which are used throughout.

${ }^{8}$ Experiment taken from Gibson-Graham meaning: 'what can we learn from what is happening on the ground.' In experimentation there is no active transformative subject 'learning about' a separate inert object, but a subject-object that is a 'becoming world' (2011:4). For more on geographies of experiment see Last (2012), Powell and Vasudevan (2007), and Thrift (2011)
} 
As noted already, for Rose (2016) stories from the field provide the conditions for thought and in turn for theoretical and conceptual innovation. This section shows that theatre can expand how stories, scenes, and theories are co-developed in human geography in ways that can prioritise the lived experiences of otherwise 'less-heard' and/or marginalised research partners. These processes may not always lead to direct action but can enable a politics of 'small changes.' However, like other methods, theatre also has the potential to reproduce colonisations of body and voice, to further embed settled hierarchies, and to exclude those who do not feel the desire, the right, or the capacity to speak or perform with others. In this context recognising the broad range of approaches that are available and how they engage differently with voice, narrative and dialogue, matters. It is vital to critically interrogate how dialogue takes place, which stories circulate, and to recognise barriers that might constrain or block speech from flowing. In line with politics and ethics in PAR (participatory action research) some of these processes may involve participative forms of reflection (Kindon et al., 2007).

As theory-practitioners in applied theatre suggest 'not only do researchers want to give voice to their participants as equals in the enquiry, they are also interested in making their data more accessible to those on whom it is based' (Clemson and Ntelioglou, 2014: 234). However squeamish I am about the language of 'giving voice' (since for me it makes assumptions and reproduces entrenched hierarchies) this emphasizes opportunity that theatre as method affords for listening to and engaging with differently situated narratives through the co-production and co-analysis of research across the research/ performance continuum (Beck et al, 2011). Participatory geographers have drawn on arts practices to foreground embedded expertise and to recognize the significance of contexts through which knowledge and pathways to action are produced (Pain, 2004; Kindon et. al, 2007; mrs. Kinpiasby, 2008; Askins and Pain, 2008; Askins, 2009). Given an emphasis on action, inclusion, and emotion it is no surprise that amongst a broad range of creative methods, social scientists have deployed theatre practice for their participatory potentialities (Houston and Pulido, 2002; Nagar, 2002; Pratt and Kirby, 2003; Kaptani and Yuval-Davis, 2008). For Cieri and McCauley (2007) the creation and presentation of theatre is a site of participatory action research. They describe a dialogic process whereby actor/ collaborators and artist/researchers collected 'untold' stories about three charged historic events: the 1960's voting rights struggle in Mississippi; the mid 1970's school desegregation controversy in Boston; and the 1969 Black Panther Party - Los Angeles Police department conflict. Researchers and community-based actors assembled transcripts into a narrative collage, which was re-told in performance. Here embodied moments of 'retelling' about 'pain and grief, struggle and triumph' became cited as a reason for their resonance with audiences (Cieri and McCauley, 2007: 146). In this case we see how theatre practice might make stories visceral to those who had not yet encountered them, as they are enlivened in performance. 
However, Mattingly (2001) shows how entrenched asymmetries may be reproduced through performance. In City Heights, San Diego, an 'impoverished, multi-ethnic neighbourhood,' interviews were used to prioritise the marginalised voices of residents, which were staged by teenagers in a local school. The performance ultimately presented a harmonious vision of the region, which supported broader efforts at urban regeneration but did not resonate with performers own experiences of the city. Mattingly claims that collaborators stories were embedded in specific contexts and would be received as such since, 'putting people's voices on stage does not necessarily give people power over the institutional and symbolic contexts in which their voices are heard...' (Mattingly, 2001: 457). Boal (1992) notes that dramatic devices can re-enforce established social conditions. Simply gathering, assembling and staging stories may reproduce institutional colonisations of 'voice,' and re-assert norms and conventions which become embedded in particular circumstances; if care is not given to how scenes are organised, presented or received. Despite this, as Boal $(1979,1992)$ also advocates, uses of theatre can be used to surface, disrupt and intervene in settled formations of order.

Most notably, in geography Pratt and Johnston (2010, 2012) engage with Boal's (1979) techniques for a 'theatre of the oppressed.' Through uses of forum theatre dialogue takes place between actors and 'spect-actors' who can question, step in and alter the trajectory of a narrative. This practice becomes framed as a rehearsal for social action. Devices may also be used in attempts to inform local governance via 'legislative theatre' (Pratt and Johnston, 2007, after Boal, 1998) and to enhance public engagement with neighbourhood planning (Cowie, 2017). In other cases theatre practice is used to develop story collaboratively, this can be orientated towards action and advocacy for social change. For example, Pratt and Kirby (2003) show collaborators engaged in story-telling workshops (alongside other methods) in a project with nurses in union struggles over pay. After a play-back of the script in rehearsal, nurse collaborators were not happy with how their testimonies had been translated. As one interviewee suggested 'I don't believe that you can hire a writer who has a preconceived idea about nursing- you need to listen to us' (Pratt and Kirby, 2003: 23). Following negotiation the script was changed- with mixed results. However tense this outcome, the practice of playing back narratives, allowed collaborators to invest in the performance as a research outcome and opened space for discussion about the realities of nursing and a politics of (mis) representation.

For Pratt and Kirby (2003) theatre provided a 'safe space' where nurses could let their guard down about the practical and political pressures of the job. The space between reality and fiction enabled experimentation (Kershaw 2000) 'ironically the fictional and farcical parts of the script allowed space to raise hard hitting and very specific criticisms of hospital administrators' (Pratt and Kirby, 2003: 19). However theatre as a safe space was complicated by the exposure of collaborators in performance: nurses were uncomfortable performing back at their own hospitals. This may also present a 
challenge in some uses of forum theatre, where, despite the careful construction of conditions that enable participation, spect-actors might resist speaking out in public for a wide range of reasons (rights and capacities to speak are circumstantial, on which see Rodenburg, 2015). Despite this, actors are sometimes employed to 'play-back' narratives, to protect the anonymity of research collaborators (Richardson, 2015) and forum and/or other techniques can be practiced outside of public performance. As I go on to show, our own process involved a combination of these strategies.

In Gateshead, UK, theatre-maker Donna Tonkinson and I spent six weeks facilitating theatre-making workshops with women participants at the family support service. ${ }^{9}$ In the following two years that I spent participating with the group, I/we wrote a fictional play. Drafts in progress were work-shopped and played back to women twice for feedback using paid actors, until finally the production was staged. Over that extended period, different kinds of knowledge and expertise were drawn together. This is significant in relation to one key pedagogic basis of PAR. For Friere (1972) 'doing' provides the basis for a particular depth of learning. Theatre- practice gives certain kinds of access to collaborators lived experiences and these were brought into dialogue with my own knowledges and experiences. For example, I had been reading approaches to precarity and precaritisation in relation to a UK austerity climate (work from Lorey, 2011; and Puar et al., 2012 were of particular note). During that time, I also had a visceral response to Berlant's (2012) diagnosis of 'cruel optimism' in a postfinancial crisis climate. This gave form and additional insight to my own lived experiences - it made them palpable in particular ways. However, when these intellectual perspectives were brought into dialogue with other women's experiences of uncertainty my/our understanding of them shifted again. So where Cerwonka and Malkki (2007) describe a weaving of theory and empirics that occurs through the body of the researcher in ethnography, here that process of weaving was expanded to include co-researchers in a (messy) process of mutual learning.

A script-development exercise, where we created characters in a space between fiction and non-fiction illustrates this process in action. After drawing around two women on a large piece of paper (the 'roll on the wall') we chose a name, age, and current situation: e.g. Sandra, 29 single parent not in paid work; Julia, 49 recent divorcee without children. Then we asked the following questions:

$1 \quad$ How does the character feel about herself?

2 How does the character feel about other people?

3 What does the character think about her life and/or events?

\footnotetext{
${ }^{9} \mathrm{I}$, in particular, was learning 'on the job' through this process. We improvised with a range of approaches gleaned through research and practice with other
} organizations including Live Theatre, Magic If, Geese Theatre Company, Them Wifies and Open Clasp. 
4 What do other people think about the character?

5 What are her likes and dislikes?

6 Her history?

$7 \quad$ Her dreams or regrets?

Women discussed issues including but not limited to 'money worries,' 'feeling angry and upset at my ex-husband and worried about my mam,' 'having hopes for the future of my children,' 'hopes for getting a car,' 'getting driving lessons,' 'getting on the housing list.' In another exercise we tracked significant events in the life of each character such as marriage, forms of employment, being in social care, redundancy, divorce, and child-birth. This enabled in-depth discussion about the desires of research collaborators and their conditions over time. We practiced careful acts of listening- to one another's experience, to the demands of the story and the project. And we made decisions to construct fictional characters. At times in this process, rather (or as well as) a (fragmented) map of women's life events being applied to particular literatures in a 'write-up,' stories from the academy were brought into dialogue with collaborators. We noticed patterns (and disconnects) between women's own experiences and existing research on, for example, optimism and stigma. Because what we created were fictions, they did not reduce, capture or represent the lives of women with precision or accuracy. Instead characters became part of the doing of these collective stories. They were generative of discussion, debate, and in turn, a rich range of research materials, including records of our processes and conversations, the characters as they appeared in our final script and in development, the time-line, and the roll on the wall.

One promise has been that theatre opens space for dialogue and in situations of adversity acts as a rehearsal for ground-up social and political change, for example as 'spect-actors' step in and change the trajectory of a narrative. Story can be cocreated in a playful space between reality and fiction with more diffuse, less tangible impacts (on a theatre of little changes see Balfour, 2009). We did not aim to achieve direct action in relation to a particular issue. The fictional play and associated research material enabled dialogue to take place, it evoked and expressed women's lived experiences to local audiences, materialising otherwise invisible effects of austerity. These practices of coproduction show how geographers can work with theatre-makers and other collaborating partners to mediate iterative learning. Furthermore, the kinds of doing enabled by theatre-making practices resonate with the concept of 'vivencia' which does and does not quite translate into 'participation' and 'experience' in PAR. Vivencia is the embedded and embodied knowledge formed through actually living a situation. It is the 'full experience of an event' (Glassman and Erden, 2014:212.) In our project this refers to how stigma, relative poverty and austerity was lived by women (who embody but are not reducible to these experiences) and to immersive experiences 
mediated by theatre-making practices - which facilitate the sharing, sensing, feeling and thinking of that knowledge. I take this focus on immersive experience forward in the next section as I think about theatre practices that mediate collective experiments with feelings and emotion.

\section{Feeling affect: Mediating the immediate}

Theatre offers opportunities for geographers to think and move in particular ways with others for the co-generation of research. Specifically, it can open space for collaborators to materialise and reflect on affective conditions, which may otherwise remain in the background. ${ }^{10}$ This can contribute to current methods used in non-representational theories, which are largely immersive and participative. McCormack (2008:4) points to a long philosophical tradition 'in which experience and experiment are valorised as necessary elements of thinking.' Perhaps for this reason non-representational theories have played a significant role in the 'creative (re)turn' in human geography. Central to this are questions concerning the becoming palpable of affective forces and flows via a range of practices (Anderson and Harrison, 2012; Anderson, 2014). Nonrepresentational theories enact most simply an interest in 'the geography of what happens (...) [they are] therefore a work of description of the bare bones of actual occasions' (Thrift, 2007: 2). Non-representational geographers do not seek to uncover '....meanings and values that apparently await discovery, interpretation, judgment and ultimate representation...' (Lorimer, 2005:84). Instead, a significant proportion of this work has become occupied with immersion of the researcher in sites and practices so that they might experience particular phenomena - becoming attuned to forces and flows that affect the body. In this way participation becomes synonymous with a kind of proximity to the excesses of performance either explicitly or by implication. For example, geographers have performed a series of practices such as walking (Wylie, 2005) hanging around (Swanton, 2010) and commuting (Bissell 2010) foregrounding what happens with and in excess of cognitive thought (Thrift, 2007; Grosz, 2013) before writing about their experiences of these practices.

Increasingly experiments in expressing 'what happens,' take place and the lines between doing and documenting are intentionally blurred. For example Macphearson and Bleasdale (2012) deploy practices for exploring space; tagging with masking tape, making ink journeys using the dancing body. Relatedly, artist-geographer Boyd (2017b) translates 'felt' knowledges into visual, auditory, and haptic forms through creative writing, material experimentation, audio-visual works, and musical improvisation.' For McCormack (2004, 2008, 2014) dance is a key site for complicating questions of representation because it is so difficult to replicate. Dance practice (and drawing) becomes just one possible 'field of variation in which to experiment with the question of how felt differences might register in thinking' (McCormack, 2014: 
11, also see Dewsbury, 2011; Merrimen, 2010; Nash, 2000). Furthermore, Veal (2015) turns to the choreographer's notebook as a tool for both documenting and practicing dance and what dance does. Baranje and Johnson (2014) describe the liminal spaces of a street theatre project alongside its capacity to generate empathetic encounters and Johnston and Lorimer (2013) describe Vancouver-based sensory experiment, 'Do You See What I Mean?' Here, in an urban choreography audience members are blindfolded, given an immersive tour of public spaces, shops and private homes, and then led by a professional dancer in contact improvisation to explore a 'heightened sense of embodiment garnered through the tour' (Johnston and Lorimer, 2013: 675). Attention to 'the felt world' is foregrounded and the project captures innovative methods for participants to differently engage with the city using their senses. The lived affects of this work may be investigated both in the moment of doing-documenting, and in later writings. In many instances reflections on how experience impacts on thinking (both via a particular activity and what that activity might reveal about everyday life) take place after the event, and not in collaboration with research participants. However, we can create more spaces for these kinds of critical reflection to become embedded within a participative process. I show this through uses of theatre for research, as I ask: what other methods are available for attuning and responding to how affects become palpable as feelingsthrough theatre practice? How might they enable the kinds of iterative, practice-based learning that I described in the previous section?

I begin with the games and exercises that we facilitated at the start and end of every session. These expanded vocabularies for collaboration (author 2017). We played with norms and conventions not just through the spaces of fiction that Pratt and Kirby (2003) explore, but also through techniques that shifted how our bodies typically interacted in space. The devices took us 'outside of our comfort zone' as one collaborator described it. For example, we worked in pairs standing face-to-face, palm-to-palm, one partner mirroring the actions of the other and then vice-versa. I touched my nose. I coughed. I clenched my teeth. As my partner copied she became attuned to my body and I became attuned to hers. I took her on a journey through the room- our hands were barely touching but sweaty. We were connected and connecting viscerally, through a series of 'biological flows of energy, matter and stimulating chemical fluids (adrenaline, pheromones, endorphins)' (Dewsbury, 2000: 485). We were making and exploring space in new ways together and our interaction was mediated by the 'rules of the game'. For Boal (2002) unconventional modes of encounter open towards new ethico-political potentialities. As one woman noted: 'if everybody is silly then nobody is silly' and so boundaries of 'silliness' were renegotiated through this process. In this and other exercises we practiced mutual affirmation. One consequence was, at least for me, the development of intimacy/trust. Further, these experiences delineated a strange and safe space (Kershaw and 
Nicholson, 2011) for theatre-making inside which the familiar became unfamiliar and vice versa. It is in that unfamiliar space that unregistered or unnoticed phenomena may surface becoming objects for investigation.

Through the practice of theatre games and exercises we developed skills for both verbal and non-verbal communication. Building on these tools we could improvise scenes that would 'flesh out' our fictional characters. In one case collaborators worked in pairs to create a scene in the job centre. Then they showed this back to the rest of the group. ${ }^{11}$

SARAH: Number?

SANDRA: What do you mean number?

SARAH: $\quad$ You need a number?

SANDRA: $\quad$ Oh, yeah, here.

SARAH: It doesn't register. You need another one.

SANDRA: But... I've just waited for nearly 45 minutes!

SARAH: This number is incorrect.

SANDRA: Can you not ring across or something?

SARAH: It's not my problem.

SANDRA: $\quad$ But, she gave me the wrong number...

SARAH: It's not my problem

SANDRA: $\quad$ But, well, I mean . . . she's getting hungry (starts rocking her arms as though with a baby)

SARAH: $\quad$ Are you refusing to comply?

SANDRA: Well no but...

SARAH: $\quad$ You need to get another number...

In this scene tension built as the baby became agitated. Sandra joined queue after queue, she attempted to breastfeed and was reprimanded for doing so. She was late and nearing breaking point. Her body was always on the move, rocking the baby, looking around, anxious, frantically paddling just to keep still. Sarah was motionless and uncompromised. The actors' singular, intimate performances exceeded words on this page. We stopped the action and asked actors to describe (in character) how they felt. Here we could explore and reflect on the affective resonance and significance of this performance. Further, something mediated in this moment surfaced again and again beyond the scene through descriptions, enactments,

\footnotetext{
${ }^{11}$ This is an edited version of the improvisation, written at the time of performance. It is notable that the scene resonates with one later developed in the
} film I, Daniel Blake (2016) 
portrayals of women feeling pulled in multiple directions, bulldozed, unheard, forced to make un-actionable decisions. This performance was both irreducible and resonated into subsequent performances. These feelings became a key refrain in the final play. This made precarity as a lived and felt condition visceral. The performance was singular, specific and within given circumstances generic, common, mutually understood. We see then how techniques for improvisation materialized particular feelings in performance. We could discuss and gain insights into contemporary conditions including women's situations as out of paid work, as parents in a region with an insufficient supply of paid labour, as lone mothers in dialogue with the mapping activity described above. Through this process we did not attempt to uncover or explain a whole, or total phenomena, but we could discuss and explore patterns shaped by shared or generic conditions as they surfaced through singular performances (Amoore, 2018, Author 2016).

Women's everyday experiences were animated as they became in relation with theatre practice, through a form of movement or dialogue. In this way we could engage with 'the bare bones of what happened' during these and other moments of animation. We did not pre-empt, or attempt to accurately represent; that is fix, limit or reduce women's everyday experiences and encounters. Instead, collaborators could work together to evoke and discuss affective encounters in spaces made strange by fiction and by games and exercises that encouraged experimental forms of embodied interaction. If Anderson and Harrison (2010) describe the act of entering a room and sitting on a chair that would typically take place in the background, in the strange space delineated by theatre games and exercises, sitting on a chair may no longer be taken for granted. Further, this act could be questioned, challenged, played around with. Similarly women's everyday experiences at the job centre could be engaged with differently in the space of theatre than in everyday life. How these events were felt became palpable in performance. Ways of learning together were facilitated through shared acts of doing - theatre making. In this way, if Bissell (2015) described the significance of non-verbal cues for attuning to stressed-bodies in interview analysis then theatre expands methods for sharing, expressing and sensing embodied experiences with others with and in excess of words (also see Kanngieser, 2011, on the multiplicity of voice). Not just what we said but how we said it mattered to the feeling in and of a performance. These utterances became part of the singularity of a performance and evoked something more generic, something made common via accent, tone and emotion. Just as McCormack (2015) both animates and shows the impossibility of ever really capturing movement through written words and line drawings, theatre improvisation, games and exercises may evoke and simultaneously exceed and escape women's everyday experiences. I consider instead, how the field of possibility for the research event is conditioned by our different experiences and theatre-making itself becomes part of that experience. In this way, improvisation extends the tools that geographers draw on to experiment with affect through a disruptive combination of doing and documenting in collaboration. Both the singularity/ creative potentiality of 
performing bodies and the shared/ generic conditions that frame their possibility are held together; and through this process collective forms of doing impact on the kinds of knowledge that are generated.

\section{Mattering: bodies becoming singular and generic}

There is, of course, more to say about the significance of theatre for co-produced research on and with the body. Here I show how uses of theatre provide occasion to disrupt 'disembodied voices of academia and voiceless bodies colonised for knowledge' in human geography (Crang, 2003: 499 quoting Spry, 2001: 718). This pushes further at how the different bodies of collaborators matter in the making and dissemination of theatre for research and speaks to (touches) geographies of the body and bodily difference. A series of feminist interventions in the 1990's placed the body firmly on the geographical map. This work centred the significance of embodied knowledges (Rose, 1993; Longhurt, 1997) pointing to the spatiality of the fleshy corporeal body, which has surfaces, boundaries and leakages (McDowell and Sharpe, 1997). Despite an expanding range of work with and on the body in human geographies, Longhurst and Johnston (2014) have identified need for methodological 'catch- up.' Theatre-practices (amongst other forms of performing arts) are well-placed to respond to this.

There are many over-laps between geographies of bodily difference and some of the non-representational approaches explored in the previous section (Colls, 2012). Emphasis here is on further connecting geographies of embodiment with a politics of bodily difference. A re-thinking of the body in philosophy, sociology, cultural studies, gender and queer studies has been influential in geography and I draw on these influences here. In particular, how post-structural feminisms theorise bodies that are produced by, but also exceed how social conditions 'get inside,' (for example see Grosz, 1994) and Blackman, 2012). Such ways of knowing the body invoke a necessity to better understand what mediations, including representations, of bodies (in and beyond our research) do to the body.

For Butler (1993) it is only by moving out-with the body that we can we truly understand it. This refers to a concern with how discursive iterations produce norms that stabilise conditions for identity formation - including acts of subversion. As noted already, some cultural geographers suggest that too much emphasis on the linguistic model risks writing out other forces in the co-constitution of embodied experience including technologies, practices, and inter-subjectivities (Nelson, 1993; Thrift and Dewsbury, 2000). However theories of performativity enable us to explore and move beyond how discourses dominate, if we attend to other forms of sociality that materialise in the body. ${ }^{12}$ In this way, rather than 'writing out' the embodied effects of language (and other cultural forms) or denying the often violent ways in which different bodies

\footnotetext{
${ }^{12}$ For one framing of this turn, see Dolphijn and van der Tuin (2012) on 'feminist new materialisms,' Ahmed's (2008) critique of the novelty of a 'turn to matter' as well as Davis (2009) in response to that critique.
} 
are organised and mediated differently, some geographers have turned to analysis of 'what happens' to different bodies - as they become in relation to social and cultural practices (Longhurst and Johnson, 2014). These may liberate, include, affirm, and/or reduce, debilitate, constrain or exclude (Anderson, 2018).

In sociology Coleman (2008) shows how representations - in this case images of girls - inform the lived experiences of girls and women. Relatedly, Berlant (2008) refers to sexual identities like 'genres' which stretch out and organise lives, are felt, performed and entered into, however ambivalently (Jackson, 2015). Foregrounding how different bodies are silenced, excluded or included Puar (2013) engages with an intersectionality 'in motion' (after Lorde, 1984). Further, she moves away from the pre-emptive formation of distinct 'able-bodied' and 'disabled' identities to explore how embodied-subjects become enabled and/or debilitated as they move through time-space. These states of debility are a result of relations between bodies, discourses, architectures, and technologies (Puar, 2017). This assemblage-based approach exemplifies ways in which 'positioning does not precede movement but rather is induced by it,' (Puar, 2013:49). This necessitates the question of how bodies materialise as they encounter social and cultural forces rather than what they signify (Puar, 2013:58). These diverse perspectives show how opportunities for bodies to become affirmed in relation to worlds are distributed asymmetrically. Explicitly or implicitly, bodies are unique in this work, but they are also generic. They are individuated at a nexus of force and recognised, resonant, when the forces that compose these bodies are held in common. There are opportunities for thinking/doing embedded, situated, creative research to explore the effects on the body of social and cultural genres that are shared or held in common, yet may be taken for granted or un-noted. Holding onto the singularity of research collaborators during these processes becomes part of the creative act.

Noxolo's (2015) work with African-Caribbean dance as a form of mapping is especially useful for thinking through these issues. Whilst it is broadly understood in human geography that bodies make places (as well as being made by places) for Noxolo, in popular culture black bodies are often emptied of that agency in European contexts. These are the effects of genres of colonialism, of historic and institutional forms of racism. The performance of African-Caribbean dance as cartography however, proclaims the rights of black bodies to make and become embedded within European places from which they have been hitherto marginalised. But further, the subversion of form used for mapping shifts a colonial form of making, fixing, owning place, towards an affirmative form of immanent, lively and celebratory dance cartography. Dance is movement - and through that movement the making of space is not fixed, but becomes fleshy, emotive, open-ended. In this way the practice of dance does and documents the singularity of African-Caribbean performers and it pushes against shared forces that impact on those performers and black bodies generally. In this way the dance facilitates a shared encounter that gets inside the body, that becomes an inclusive and affirmative act. 
Pratt and Johnston's (2013) Nanay: A testimonial play involved the staging of talk-based research material from Filipina caregivers, employers, and other stakeholders engaged in Canada's Live-In Care-Givers Program. Canadian 'employer' and Filipina 'employee' materialised and exceeded the generic terms of their situations beyond language in this performance. Harmful effects of the Care-Givers program that were hidden for some and lived by others surfaced viscerally, and could be challenged in this moment of staged encounter. But further, when this performance travelled to the Philippines, the specific and embedded Canadian viewpoints that it presented were contested, 'the same testimony takes on different meanings in different contexts' (Pratt, Johnston and Banta, 2017: 68). As a result of this travel, a messy process of learning and unlearning ensued. This was made possible because the play materialised these embodied, situated, knowledges, and because space was made for their contestation. What took place between bodies in, and witnessing the performance, and the significance of how/where those bodies were situated, was central to, and not 'written out' in this research practice.

Amidst a body of work with theatre Rogers (2010) considers what materialises in performance as she reflects on the rehearsal of scripted Asian-American play Solve for X. Although this (re)produced what she described as 'essentialist' representations of racial identities, bodily enactments of these representations enabled other possibilities to emerge. In the moment of performance the text became singular - enlivened, open to excess, slippage and surprise through the acting body (Rogers, 2010: 55). Something generic (words on a page) and something singular (the individuated body performing that text in any given moment) become in relation. This is important for understanding the significance of performance-based research for geographies of the body and bodily difference. I go on to explore how performing arts and theatre methods can enable the collaborative disruption and interrogation of shared or generic forces that organize different bodies differently, whilst holding onto the singularity and potentiality of individual collaborators. Through these processes, often-excluded bodies can become central to the development and at times the dissemination of co-produced research.

As I have already explained, we engaged with working class women in the North East of England. Many of these women were single parents and not in paid work. At times they registered the visceral effects of a flourishing genre of 'poverty porn' in the UK (Jenson, 2014) alongside political rhetoric that demonized benefits claimants and supported the legitimation of welfare cuts (author, 2016). Some women sought to distance themselves from that genre despite its effects in their everyday lives; some discussed stigma in relation to their social-economic situation, some normalised and internalised negative stories. One woman described being attacked by a stranger on a bus for 'having so many kids' and 'being out of work.' However, through the staging of a fictional play we could notice, explore and push back against the effects of a genre that depicted women out of paid work as shirkers and as a drain on society (Author 2016). We could also work through some of our own 
prejudices and often un-thought practices of 'micro-othering.' Amidst some of the other processes that I have described, this intervention happened through the construction of images formed using the body as well as words.

In one session we turned attention towards collaborators' experiences and perceptions of femininity. Donna asked the group (of 12) to split into two and each made an advert selling 'benefits of being a woman'. The group to which I was assigned used voice-over to accompany a range of mimed actions. Women's suggestions included: 'having boobs,' 'getting dinner bought for you by your boyfriend or husband,' 'being daddy's little girl' and 'having Ann Summers parties'. The exercise was invested in with fun and gusto. Hannah sassed across the room swinging her hips and celebrating her curvy body. Robyn laughed whilst thrusting at a mimed dildo. In this scene one expression of womanhood was playing together and feeling the fun, intimacy and trust in that. This evoked a promise of belonging that Berlant (2008) describes in relation to feminine identity as a genre. However, the exercise also revealed and reproduced particular heteronormative constitutions of women becoming in relation to men that felt uncomfortable to me. ${ }^{13}$ We could sit with and discuss this discomfort since the scenes had become available as objects for analysis.

The other group worked on a 'still-image.' Women came together to embody an octopus like figure - one on the phone, one holding a baby, one scrubbing the floor, one typing at a desk, one cooking, and one shopping. Bella said that this reflected what it feels like being a woman - 'like you've got to manage a million different things at once.' Women are brilliant the group concluded because they are so good at multi-tasking. I sensed a pressure here too, to be that phantasmagorical octopus woman. To be all things to all people. There were assumptions embedded in this performance about the 'modern woman' juggling paid and unpaid work. This felt confining in a different way to the previous scene. It was surprising in its omission of 'mother out of paid work' as a valid expression of womanhood. But it also resonated with some of the broader themes and feelings, for example of being pulled in multiple directions that appeared throughout the rest of the process and have been discussed in previous parts.

In this exercise many bodies formed into one body. I was drawn to Bella who was positioned in the middle of the scene. I try to capture her here. I delete the words and try again as I attempt to escape fixing or reducing her, but fail. Bella was standing straight, proudly, tall, fat, tanned, brown hair, a pony tail, jeans, a tracksuit top: 'clever,' 'strong,' 'vulnerable,' 'stubborn,' 'committed,' and more than all of that. Singular, indeterminate Bella. Superwoman pose: variously embodying and exceeding genres of women, class, and the North East of England. These exercises presented a creative embodiment of

\footnotetext{
${ }^{13}$ This is complicated - to what extend does the exercise that I describe become part of the genre of 'poverty porn' that I have denounced? I write what happened, and how I felt about it. We discussed those images; they were not available for public consumption (until this point) and now they are used in the
} context of a broader discussion, as follows. 
womanhood and they revealed how genres of womanhood had become embodied. In this way the scene we created shifted, and held traces of other scenes that women had encountered.

This process demonstrates the holding together of singular women with conditions that organise them; that they perform and embody. We can see that how and where these bodies are situated matters. Theatre as method offers particular opportunities for the collaborative 'critique, intuition and analysis' (Berlant \& McCabe, 2011) of conditions that materialise in singular bodies and moments (through theatre practice) without necessarily reducing characters, or performers only to the effects of forces. For example, when women perform 'womanhood' in a still image this materialises patterns in their perceptions about what women should be. In performance 'white working class women' at once embody, subvert and exceed the lived effects of these categorisations. In this way the body becomes central to collaborative research-creation, both as a tool and an object of analysis. Research collaborators matter as their embodied experiences become integral to the collaborative process, but further as the forces that get inside these bodies materialise, they become available for reflection and subversion - using the body (with and without words) in and through the strange theatre-making process. There are opportunities then, for hitherto marginalised bodies to become visible, present, in performance; but also processes through which we can attune to, explore and perhaps intervene in, the conditions of marginality.

\section{Conclusion: 'When flesh utters and words move... 14}

There are many opportunities for collaborative research using theatre practices that may be 'fleshy and emotional;' that may in different ways make the 'world come alive' (Thrift and Dewsbury, 2000: 422); that may extend a field of possibilities and so stage some form of intervention. By exploring theatre-based work already taking place in human geography, alongside our own practices, I have shown how collaborating partners 'speak,' 'feel' and 'matter,' in and through theatre for research. The effects of doing on thinking (and vice-versa) are opened up to collaborators in spaces made for mutual critique, intuition and analysis. Diverse forms of practice reveal and alienate relations between singular stories, moments, and bodies, and the generic conditions that, in part, compose them. This is significant for how other forms of collaborative, creative, practicebased research, might facilitate interventions. Geographers do not only gain new insights as they do research on (or with) other people and practices; collaborators gain and negotiate new insights together as they participate in the shared event of theatre-making. This can lead to the kinds of micro-political change that I have described, as well as forms of direct action noted in other work. Geographers need not necessarily become expert theatre-makers or artists, but can work with

\footnotetext{
${ }^{14}$ This line is taken from a piece of performance practice by Giddens and Jones, which can be found (amongst other places) featured in Machon (2009)
} 
practitioners in constructive collaborations. ${ }^{15}$ What matters is learning between partners who bring different kinds of experience with them and how this is mediated through the shared experience of a creative practice.

Theatre inevitably involves various degrees and forms of collaboration. There is opportunity for much more engagement with theatre and the broader performing arts for collaborative, practice-based research, especially for those concerned with participation, embodiment and bodily difference. My focus has been on techniques for attuning to affective flows and intensities in collaboration with others. The body becomes central as a tool and an object for analysis and this can further connect approaches to understanding a politics of affect and bodily difference. For example, theatre-based research can materialise and intervene in (some of) the work that discourses, images, technologies etc. do to organise different bodies differently. Methods can be variously enabling and/or debilitating and care is given to how, in any given process, such capacities unfold. This justifies an extension of what counts as research material, to including the doing and documenting of practice-based research. Further, it shows how ways of knowing in the subfields that I have engaged can be extended and connected by uses of theatre as method, and how they might enact different kinds of change for collaborating partners.

The practice-based (practice-led) learning demonstrated here has broader implications then, for other kinds of collaboration. I finish with some provocations: questions that those considering the value of creative, collaborative, practice-based research-interventions in human geography might consider. 1. Has this creative-research worked within and/or reestablished already embedded norms and conventions (fields of possibility) for collaborating partners (in the given frameworks of the project) or surfaced otherwise hidden or less-noticed phenomena? 2. To what extend do these phenomena become available as objects for collective analysis and what space is made to enable this? 3 . How strong and welljustified is the relationship between a creative practice and the political, conceptual or thematic ways of knowing it seeks to engage? 4. What changes in both fields as a result of the process? 5. What does the practice offer in excess of methodologies already established in a given (sub) discipline and why is this significant? These provocations offer at least another starting point for interrogating the value and sense of collaborative practice-based research, though the challenge moving forward is certainly one of evidence and evaluation.

\footnotetext{
${ }^{15}$ See Hawkins (2015) on the question: 'do geographers have to become artists?'
} 


\section{References}

Ahmed, S (2008) Open forum imaginary prohibitions: Some preliminary remarks on the founding gestures of the 'new materialism.' European Journal of Women's Studies 15 (1) 23 - 39

Allegue, L, Jones S, Kershaw, B (eds.) (2009) Practice as Research: In Performance and Screen. London: AIAA. Amoore, L (2018) Cloud geographies: Computing, data, sovereignty. Progress in Human Geography 42 (1) 4-24 Amoore, L \& Hall, A (2010) Border theatre: on the arts of security and resistance. Cultural Geographies 17 (3) 299 - 319 Anderson, B \& Harrison P (2010) Taking-Place: Non-Representational Theories and Geography. London: Ashgate Anderson, B (2018) Cultural geography II: The force of representations. Progress in Human Geography, online first Anderson, B (2014) Encountering Affect: Capacities, Apparatuses, Conditions. Farnham: Ashgate

Askins, K (2009) 'That's just what I do’: placing emotion in academic activism. Emotion, Space and Society 2 (1): 4-13 Askins, K \& Pain, R (2011) Contact zones: participation, materiality and the messiness of interaction. Environment and Planning D: Society and Space. 29 (1) 803-821 
Balfour, M (2009) The politics of intention: Looking for a theatre of little changes Research in Drama Education. The Journal of Applied Theatre and Performance 14 (3) 347-359.

Beck, J, Belliveau, G, Graham, W, \& Wager, A (2011) Delineating a spectrum of research-based theatre. Qualitative Inquiry 17 (8) 687-700.

Berlant, L (2008) The Female Complaint: The Unfinished Business of Sentimentality in American Culture. Durham: Duke University Press

Berlant, L, \& McCabe, E (2011) Depressive realism: An interview with Lauren Berlant Hypocrite Reader [online] available: http://hypocritereader.com/5/depressive-realism [27th February 2016]

Berlant, L (2012) Cruel Optimism. Durham: Duke University Press

Berlant, L (2013) Lauren Berlant in conversation with Dana Luciano Social Text [online] available: http://socialtextjournal.org/periscope_article/conversation-lauren-berlant-with-dana-luciano/ [December 2015]

Biggs, I (2011) The Spaces of Deep Mapping: a partial account. Journal of Arts and Communities, 2 (1) 5-25.

Bissell, D (2010) Passenger mobilities: affective atmospheres and the sociality of public transport. Environment and Planning D: Society and Space, 28 (2) 270-289.

Bissell, D (2014) Encountering stressed bodies: slow creep transformations and tipping points of commuting mobilities. Geoforum 51: 191- 201.

Bissell, D (2015) How environments speak: everyday mobilities, impersonal speech and the geographies of commentary. Social and Cultural Geography 16(2): 146-164.

Blackman, L (2012) Immaterial Bodies: Affect, Embodiment, Mediation. London and New York: Sage

Boal, A (1992) Games for Actors and Non Actors. London: Routledge, translated by Adrian Jackson, 2002

Boal, A (1998) Legislative Theatre: Using Performance to Make Politics. Translated by Adrian Jackson, London: Routledge, 2005

Boal, A (1979) The Theatre of the Oppressed. Translated by Charles A. and Maria-Odilia Leal Mcbride, and Emily Fryer, London: Pluto Press, 2000

Boyd C (2017a) Non-representational geographies of therapeutic art making: thinking through practice. Palgrave MacMillan UK: London

Boyd, C (2017b) http: / / www.candiceboyd.net [1 $1^{\text {st }}$ June 2017]

Butler, J, (1993) Bodies that matter: on the discursive limits of sex. London: Psychology Press

Cerwonka, A, \& Mallki, H, M (2007) Improvising Theory: Process and Temporality in Ethnographic Fieldwork. Chicago: University of Chicago Press

Cieri, M, \& McCauley, R, (2007) Participatory theatre. "Creating a source for staging an example” in the USA' In Kindon, S., Pain, R., Kesby, M. (eds) Participatory Action Research Approaches and Methods: Connecting People, Participation and Place Abingdon: Routledge: 141-149

Clemson, H, \& Ntelioglou, B, Y (2014) Editorial: New practices, new voices, new methods. Research in Drama Education: The Journal of Applied Theatre and Performance 19 (3) 231-240.

Coleman, R (2008) The Becoming of Bodies: Girls, media effects, and body image. Feminist Media Studies, 8 (2): 163-179

Colls, R (2012) Feminism, bodily difference and non-representational geographies. Transactions of the Institute of British Geographers 37 430-445. 
Conrad, D (2004) Exploring Risky Youth Experiences: Popular Theatre as a Participatory, Performative Research Method International Journal of Qualitative Methods 3(1): 12-25.

Conway, C (2015) Editorial: Aesthetics and participation Research in Drama Education: The Journal of Applied Theatre and Performance 20 (1)1-11.

Cowie, P (2017) Performing planning: understanding community participation in planning through theatre. Town Planning Review 88 (4) $401-421$

Crang, M (2003) Qualitative methods touchy, feely, look-see? Progress in Human Geography 27: 494-504.

Crenshaw, K (1989) Demarginalizing the Intersection of Race and Sex: A Black Feminist Critique of Antidiscrimination Doctrine, Feminist Theory and Antiracist Politics The University of Chicago Legal Forum Volume: Feminism in the Law: Theory, Practice and Criticism, 139-167.

Crenshaw, K (1991) Mapping the Margins: Intersectionality, Identity Politics, and Violence against Women of Color, in: Stanford Law Review (6) 1241-1299.

Davis, N (2009) 'New Materialism and Feminism's Anti-Biologism: A Response to Sara Ahmed' European Journal of Women's Studies 16 (1) $67-80$

Dewsbury, J, D (2000) Performativity and the event: Enacting a philosophy of difference. Environment and Planning D: Society and Space 18: 473-49.

Dolphijn, R, \& van der Tuin, I, (2012) New Materialism: Interviews and Cartographies. London: Open Humanities Press.

Eggleton, K, Kearns, R, Neuwelt, P (2017) Being patient, being vulnerable: exploring experiences of general practice waiting rooms through elicited drawings. Social and Cultural Geography 18 (7) 971-993

Friere P (1972) Pedagogy of the Oppressed. Harmondsworth: Penguin, 2005

Gallagher, M, \& Prior, J (2013) Sonic geographies. Progress in Human Geography 38 (2): 267 - 284

Garrett, B, L (2010) Videographic geographies: Using digital video for geographic research. Progress in Human Geography 35 (4) $521-541$

Gergen, M \& Gergen, K (2012) Playing with Purpose, Adventures in Performative Social Science (Writing Lives: Ethnographic Narratives) New York: Routledge

Gibson-Graham, J K (2011) A feminist project of belonging for the Anthropocene. Gender Place and Culture 18 (1): 1-21

Glassman, M, \& Erdem, G (2014) Participatory Action Research and Its Meanings: Vivencia, Praxis, Conscientization Adult Education Quarterly, 64: 206-222

Grosz, E (2013) Habit today: Ravisson, Bergson, Deleuze and us. Body and Society 19 (2-3): 217- 239.

Grosz, E (1994) Volatile Bodies: Towards a corporeal feminism. Indiana: Indiana University Press

Hall, B, L (1981): Participatory action research, popular knowledge and power: A personal reflection. Convergence 14 (3): 6-17

Hawkins, H (2015) Creative Geographic Methods: Knowing, Representing, Intervening. Cultural Geographies. 22, (2): 247-268

Hawkins, H (2013a) For Creative Geographies: Geography, Visual Arts and the Making of Worlds. New York: Routledge

Hawkins, H (2013b) Geography and Art, An Expanding Field: Site, the Body and Practice. Progress in Human Geography, 37 (1) 52-71. 
Haraway, D J (1991) $2^{\text {nd }}$ ed. Simians, Cyborgs and Women: The Reinvention of Nature. London: Free Association Books.

Hooks, B (1984) Feminist theory: from margin to centre (3rd ed.) New York: Routledge. 2014

Houston, D. \& Pulido, L (2002) The Work of Performativity: Staging Social Justice at the University of Southern California. Environment and Planning D: Society and Space 20 (4) 401-24.

Hunter, L (2009) Theory/Practice as Research: Explorations, Questions, and Suggestions Mapping Landscapes for Performance as Research: Scholarly Acts and Creative Cartographies edited by Riley, S R and Hunter, L 231-236. New York: Palgrave Macmillan.

Jackson, V (2015) 'The function of criticism at the present time' Loss Angeles Review of Books [online] available: https://lareviewofbooks.org/essay/function-criticism-present-time [26th June 2017]

Jenson, T (2014) Welfare Commonsense, Poverty Porn and Doxosophy Sociological Research Online 19 (3) 9

Johnston, C, \& Lorimer H, (2014) Sensing the city. Cultural Geographies 21 (4) 673-680.

Johnston, C. \& Bajrange D (2014) Street theatre as democratic politics in Ahmedabad. Antipode 46 (2) 455-476

Johnston, C, \& Pratt, G (2010) Nanay (Mother): a testimonial play. Cultural Geographies 17(1) 123-133

Jones, S (2014) Musing on the Artist-Researcher in Collaborative Practice - Bodies in Flight's Do The Wild Thing!

Redux. p-e-r-f-o-r-m-a-n-c-e , 1 (1). http://www.p-e-r-f-o-r-m-a-n-c-e.org/ [29 ${ }^{\text {th }}$ June 2017]

Kaptani, E \& Yuval-Davis, N (2008) Participatory theatre as a research methodology: Identity, performance and social action among refugees Sociological Research Online 13 (5) no pagination

Kershaw, B (1992) The Politics of Performance: Radical Theatre as a Political Intervention. London: Routledge

Kershaw, B (2000) Performance, Community and Culture. In, Lizbeth Goodman \& Jane de Gay (eds.), The Routledge Reader in Politics and Performance. London and New York: Routledge, 136-42.

Kershaw, B, \& Nicholson, H (2011) Research Methods in Theatre and Performance. Edinburgh: University of Edinburgh Press.

Kesby, M (2000) Participatory diagramming: deploying qualitative methods through an action research epistemology. Area 32 (4) 423-435

Kanngieser, A (2011) A sonic geography of voice Progress in Human Geography 36 (3) 336 - 353

Kindon, S (2003) Participatory video in geographic research: a feminist practice of looking? Area 35 (2) 142-153

Kindon, S, Pain, R, \& Kesby, M (eds) (2007) Participatory Action Research Approaches and Methods: Connecting People, Participation and Place. London: Routledge

Last, A, (2012) Experimental Geographies. cultural geographies, 6(12), 2012: 706-24.

Latham, A (2008) Research, performance, and doing human geography: some reflections on the diary-photo diary-interview method. In Oakes, T, Price, P (Eds.) The Cultural Geography Reader (pp. 68-75). New York: Routledge.

Leavy, P (2008) Method Meets Art: Arts-Based Research Practice. Guilford: Guilford Press

Lorimer, H (2003), Telling small stories: spaces of knowledge and the practice of geography. Transactions of the Institute of British Geographers, 28: 197-217. 
Lorimer, H (2005) Cultural geography: the busyness of being 'more-than-representational.' Progress in Human Geography, 29 83-94.

Longhurst, R, \& Johnston, L (2014) Bodies, Gender, Place and Culture: 21 Years on. Gender, Place and Culture and Journal of Feminist Geography 21 (3) 267-278

Longhurst, R (2001) Geography and Gender: Looking Back, Looking Forward. Progress in Human Geography 25 (4) 641 648

Lorde, A (1984) Age, Race, Class, and Sex: Women Redefining Difference. in, Sister Outsider: Essays and Speeches. New York: The Crossing Press, 114-123.

Lury, C \& Wakeford, N (2012) Inventive Methods: The Happening of the Social. London: Routledge

MacDonald, F (2014) The ruins of Erskine Beveridge. Transactions of the Institute of British Geographers, 39: 477-489.

Machon, J (2009) Sara Giddens and Simon Jones of Bodies in Flight: The In-Betweens, Where Flesh Utters and Words Move — on Flesh, Text, Space and Technologies pp 172- 183 in (Syn)aesthetics: Redefining Visceral Performance. London: Palgrave.

Macphearson, H and Bleasdale, M (2012) Journeys in ink: representing the spaces of inclusive arts practice. Cultural Geographies 19 (4) 523-534

Mattingly, D (2001) Place, teenagers and representations: lessons from a community theatre project. Social and Cultural Geography 2 (4) $445-59$.

Massey, D (2005) For Space. London: Sage Publications

Massumi, B. (2002) Parables for the Virtual: Movement, Affect, Sensation. Durham: Duke University Press,

Marston, S, and De Leeuw, S (2013) 'Creativity and Geography: Towards a Politicised Intervention', Geographical Review, 103 lii-xxv;

McCormack, D (2005) Diagramming Practice and Performance. Environment and Planning D: Society and Space 23, (1) $119-47$

McCormack, D (2008) Geographies for Moving Bodies: Thinking, Dancing, Spaces. Geography Compass 2 (6): 1822-36.

McCormack, D (2014) Refrains for Moving Bodies: Experience and Experiment in Affective Spaces. Duke University Press: Durham

McCormack, D (2017) The Circumstances of Post-Phenomenological Life Worlds. Transactions of the Institute of British Geographers, 42 (1) 2-13

McDowell, L, and Sharp, L (1997) Space, gender, knowledge: feminist readings. Michigan: Arnold

McLean (2017) (2017) Hos in the garden: staging and resisting neoliberal creativity. Environment and Planning D: Society and Space, 35(1) 38-56

Merrimen (2010) Architecture/dance: choreographing and inhabiting spacing with Anna and Lawrence Halprin. Cultural Geographies 17 (4) 427-449

mrs kinpaisby (2008) Taking stock of participatory geographies: envisioning the communiversity. Transactions of the Institute of British Geographers 33 (3) 292-299

Nagar, R (2002) Women's Theater and the Redefinitions of Public, Private, and Politics in North India. ACME: An International E-Journal for Critical Geographies 1: 55-72.

Nicholson, H (2005) Applied Drama: The Gift of Theatre. London Palgrave Macmillan 
Noxolo, P (2015) Moving Maps: African-Caribbean Dance as Embodied Mapping. In Diasporas and Cultures of Mobilities, Vol 2, Diaspora, Memory and Intimacy, (ed) Lacroix T, Barbour S, Howard D, Misrahi-Barak J, series PoCoPages, Coll.

"Horizons anglophones", Montpellier: Presses universitaires de la Méditerranée.

O’Conner, P and Anderson, M (2015) Applied Theatre: Research, Radical Departures London: Bloomsbury Methuen

Olsen, C.S, Hawkins H (2016) Archiving an urban exploration - MR NICE GUY, cooking oil drums, sterile blister packs and uncanny bikinis. Cultural geographies 23 (3) 531 - 543

Pain, R (2004) Social Geography: Participatory Research. Progress in Human Geography 28 (5) 652-663

Pearson, M (2011) Raindogs: performing the city. Cultural Geographies 19 (1) 55-69

Pearson, M and Shanks, M (2001) Theatre/Archaeology: Disciplinary Dialogue London: Routledge.

Phillips, D J (2015) Work and Play at the Threshold of Legibility: Theatre as Method and Pedagogy in Surveillance Research. Surveillance \& Society 13(1): 57-77.

Pratt, G, \& Kirby, E (2003) 'Performing nursing: the BC nurses union theatre project' ACME: An International E-Journal for Critical Human Geographies 2, 14-32

Pratt, G, \& Johnston, C (2007) Turning Theatre into Law, and Other Spaces of Politics. Cultural Geographies 14(1) 92-113

Pratt, G, \& Johnston C. (2013) Staging testimony in Nanay. Geographical Review 103, 2, 288-303

Pratt, G, Johnston, C, \& Banta, V (2017) A Traveling Script: Labour Migration, Precarity and Performance. The Drama Review 2017, 61(2), 48-70.

Puar, J (2009) Prognosis time: Towards a geopolitics of affect, debility and capacity Women and Performance: A Journal of Feminist Theory 19, 2, 161-172.

Puar, J (2012) 'I would rather be a cyborg than a goddess' Becoming-Intersectional in Assemblage Theory. PhiloSOPHIA 2 (1) $49-66$

Raynor, R (2017) Dramatising austerity: Holding a story together (and why it falls apart...) Cultural Geographies 24 (2) 193-212

Raynor, R (2017) (De)composing Habit in Theatre-as-Method GeoHumanities, 3 (1) 108-121,

Richardson, M J (2015) Theatre as safe space? Performing intergenerational narratives with men of Irish descent. Social \& Cultural Geography, 16 (6) 615-633

Rodenburg, P (2015) ( $2^{\text {nd }}$ ed) The Right To Speak: Working With The Voice. London: Methuen Bloomsbury Drama Books.

Rogers, A (2010) Geographies of performing scripted language. Cultural Geographies 17, 1, 53-75.

Rogers, A. (2012). Emotional Geographies of Method Acting in Asian American Theater. Annals of the Association of American Geographers 102(2), 423-442.

Rogers, A (2017) For Geographies of the Performing Arts: Intercultural Aesthetics, Migratory Mobility and Geopolitics. Progress in Human Geography (online First)

Rose, G (1993) Feminism and geography: the limits of geographical knowledge. Minnisota: University of Minnesota Press

Rose, M (2016) A Place for Other Stories: Authorship and Evidence in Experimental Times. Geohumanities 2 (1) 132-148 
Savage, M, Silva, E B, Beer, D (2013) Genre, Boundary Drawing and the Classificatory Imagination. Cultural Sociology (7) 2: $145-160$

Schechner R (2005) Performance Theory. London: Routledge

Simpson P (2013) Ecologies of Experience: Materiality, Sociality, and the Embodied Experience of (Street) Performing. Environment and Planning A 45(1) 180-196.

Shaw, W, \& DeLyser, D, \& Crang, M (2015) Limited by imagination alone: research methods in cultural geographies. Cultural Geographies. 22 (2) 211-215.

Skinner, E, \& Masuda, J F (2016) $\left(2^{\text {nd }}\right.$ edition) Mapping the Geography of health inequality through participatory Hiphop in Soundscapes of well-being in popular music ed. G. J. Andrews, P. Kingsbury and R. Kearns Routledge: Abingdon

Sklar, D (2001) Dancing with the Virgin, body and faith in the fiesta of Tortugas, New Mexico. Berkley: University of California Press

Spry, T (2001) Performing Autoethnography: An Embodied Methodological Praxis Qualitative Inquiry. 7 (6) 706 - 732

Swanton, D (2010) Sorting bodies: race, affect, and everyday multiculture in a mill town in northern England. Environment and Planning A 42 (10) 2332-2350

Thrift, N, \& Dewsbury, J-D (2000) Dead geographies and how to make them live. Environment and Planning D: Society and Space. 18, 411-432.

Thrift, N (2007) Non-Representational Theory: Space, Politics, Affect. London: Routledge

Thrift, N (2011) Lifeworld Inc.: And What To Do About It. Environment and Planning D: Society and Space, 29 (1), 5-26.

Thompson, J (2006) Digging up Stories: Applied Theatre, Performance and War. Manchester: Manchester University Press

Thompson, J (2009) Performance Affects. London: Palgrave Macmillan UK

Tolia-Kelly, D P (2001) Cultural Geographies in Practice: Intimate Distance: fantasy islands and English lakes. Ecumene. 8:112-119.

Vasudevan, A (2007) Geographies of Experiment. Environment and Planning A, (39) 1790-3.

Veal, C (2016) A choreographic notebook: methodological developments in qualitative geographical research. Cultural Geographies 23 (2) 221-245

Vickery, V (2015) Beyond Painting, Beyond Landscape: Working Beyond the Frame to Unsettled Representations of Landscape. GeoHumanities, 1, (2) 321-344.

Wison, H (2016) Geography and encounter: Bodies, borders, and difference. Progress in Human Geography [0nline first]

Wylie, J (2005) A single day's walking: narrating self and landscape on the South West Coast Path. Transactions of the Institute of British Geographers, 30, 234-247.

Wylie, J (2006) Smoothlands: fragments/landscapes/fragments. Cultural Geographies 13 (3) 458-465 
